\title{
AL-GAZĀLI'́'S CRITIQUE AGAINST \\ THE MUSLIM PHILOSOPHERS \\ IN TAHĀFUT AL-FALĀSIFAH
}

\section{Qurrotul Aini}

STAI Al-Falah As-Sunniyah Kencong-Jember, Jawa Timur Email: jayaaini@gmail.com

\begin{abstract}
This article discusses al-Gazālìss critiques in his Tabäfut al-Faläsifah against the Muslim. It answers two main questions: First, what is the purpose of al-Gazāī in writing Tahäfut alFalasifah? Second, is it true that this work represent the conflict between philosophy and dogma, between revelation and the ratio, or between orthodoxy and hetherodoxy? Content analysis and historical method are used to elucidate the criticism of al-Gazàlī against the Muslim philosophers in Tahäfut al-Faläsifah. This study shows that instead of questioning the validity of logic on philosophical reasoning and methodology, al-Gazālī w rote Tahäfut al-Faläsifah in order to contest epistemological philosophical superiority claims advanced by Muslim philosophers. The critism of al-Gazâli cannot be seen as a reaction, or let alone rejection, of orthodoxy or dogma against the philosophy. Rather, his critical thought should be viewed as his attempt as a Muslim scholar to accept and adapt Greek philosophical tradition into the framework of Islamic thought.
\end{abstract}

Keywords: Criticism, Al-Gazäli, Muslim philosophers, Tabäfut alFaläsifah, Greek philosophers

DOI: http:/ /dx.doi.org/10.20414/ujis.v20i1.805 


\section{Introduction}

ABŪ HâAMID Muhammad ibn Muhammad al-Gazālī wrote Maqāsid al-Falāisifa, an exposition about the teaching of philosophy taught by Ibn Sinā. In his works which talk about ethics and psychology, like Mìān al-'Amal, Ibyà' 'Ulüm al-Din, and Ma'árij al-Quds fì Madärij Ma'rifah al-Nafs, he exposed his ethical and psychological system that is apparently inherited from Ibn Sīnā. He also wrote a number of books which confirm the support of Aristotelian logic and advocate his theologian fellows and jurist, in order to adopt and exploit the logic in their discipline, i.e. Míyär al-Ilm, Miḥak al-Nazar, dan al-Qistās alMustaqim. He even slipped a chapter that contains the introduction of logic in his main paper about al-Ușül al-Fiqh; alMustasfā min 'Ilm al-Ușül.' In the other part, in his famous work, Tahäfut al-Falāsifah, al-Gazālī criticized twenty precepts of philosophy which were considered incorect. Not only that, in Khatimah, or the cover of the book, he even argued that three of the twenty are contrary to the precept of Islamic doctrine. Those three precepts include: (1) natural azali; (2) God's knowledge about the general aspects of the nature, not the particular; and (3) the spiritual dimension of the reward and punishment in the afterlife.

The Muslim philosophers who believed in the third precept have lapsed. Therefore, they deserve to be punished firmly by Shari'ah, i.e. given the death punishment. ${ }^{2}$ Al-Gazālī repeated this fatwa in some of his other works such us Faysal al-Tafriqah, Ibyà' 'Ulüm al-Dìn, dan al-Munqidh min al-Paaläl. ${ }^{3}$ How do we

${ }_{1}^{1}$ Abū Hāmid Muhammad ibn Muhammad al-Gazālī, al-Mustasfā min Tlm al-Usūul vol. 4, ed. Hảamzah ibn Zuhayr Hāfiz (Madinah: al-Jāmi‘ah alIslāmiyyah, Kulliyyat al-Sharīah, 1992 M), 20-175.

2Abū Hāmid Muhammad ibn Muhammad al-Gazālī, The Incoherence of the Philosophers (Tahäfut al-Faläsifah): English-Arabic edition, trans., Michael E. Marmura (Provo, Utah: Brigham Young University Press, 2000), 226-227.

3 See Abū Hāmid Muhammad ibn Muhammad al-Gazāti, Fayșal alTafriqah bayn al-Islàm wa al-Zandaqah, ed. Mạ̣mūd Bìjū (Damaskus: alMațba'ah al-'Ilmiyyah, 1993), 56-60. In that book, al-Gazālī only mentions the physical resurrection and the knowledge of God; Ibyä' Ulüm al-Din (Bayrūt: Dār al-Ma'rifah, 1982), 22; al-Munqidh min al-Ḍalāl (Erreur et 
explain this mismatch? Borrowing the famous phrase from Ibn Tufyal, "Why is al-Gazāli in a time so tight but in other time he was being loose?" against philosophy. ${ }^{4}$

The reviewers of al-Gazālì's reasoning generally perceive his criticism of Islamic philosophy in the Tahafut is part of the conflict between philosphy and dogma, between revelation and the ratio, or between orthodoxy and hetherodoxy. ${ }^{5}$ Since alGazālī is a representation of the "dogma" or "orthodoxy" while philosophy represents the "rationalism" and "heterodoxy", a number of authors stress that criticism of al-Gazāli to philosophy has a destructive impact on Islamic thought. Tamim Ansari, in his famous work Destiny Destrupted, described al-Gazālī as Asy'ari theologian who argued that "faith is never possible based on the ratio but it is only on revelation". "In short, alGazālī had provided 'ammunition' to 'people who want to turn away from philosophy and natural science' to 'appear respectable and intelligent when they were opposing to the philosophy and reason". ${ }^{7}$

\section{Al-Gazālī Encounters with Philosophical Tradition.}

There is no accurate information about the birth of alGazālī. 'Abd al-Gāfir al-Fārisī, the first historians who wrote the biography of al-Gazāli, did not provide information about the year of his birth. ${ }^{8}$ Ibn al-Jawzī (d. 597/1201) predicted theat he

deliverance): Arabic-Frenc edition, trans., Farid Jabre (Beirut: Commission Libanaise pour la Traduction des Chefs-d ${ }^{e e}$ Oeuvre, 1969), 23-24.

4Ibn Țufayl, Hayy ibn Yaqzāin: A Philosophical Tale, trans., Lenn E. Goodman (New York: Twayne Publishers, 1972), 101.

5See Majid Fakhry, A History of Islamic Philosophy (3rd edition) (New York: Columbia University Press, 2004), 223-239.

'Tamim Ansary, Destiny Disrupted: A History of the World through Islamic Eyes (New York: PublicAffairs, 2009), 110.

7Ibid., 112, 113. Italics are from the writer.

$8^{e}$ Abd al-Gāfir al-Fārisī wrote the biography of al-Gazāī in al-Siyāq liTärikeh Naysäbür that has been lost. The biography text comes to us through excerpts or summaries in the works of the next historians. The long version is available in Tàj al-Dīn al-Subkī, Tabaqāt al-Shäfíryyah al-Kubra, ed. 'Abd al-

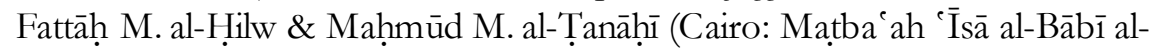
Halabī, 1968), 203-214; in short version in Ibrāhīm ibn Muhammad al- 
was born in 450 / 1058. ${ }^{9}$ Ibn Khallikān (d. 681/1282) also mentioned these dates and also other opinions stating that he was born in the year of 451/1059. ${ }^{10}$ Recently, Frank Griffel suggested the dates are so far the most accurate opinion and based on the autobiographical record of al-Gazālī, i.e. his personal letters. He argued that al-Gazālī was probably born between 446/1054 and 448/1057, maybe in 448 1506-7.11

According to Taj al-dinal-Subki (d. 771/1370), al-Gazālī came from a poor family but they are pious. It was stated that her father was illiterate. He lived with spinning the wool, a profession called al-Gazzāl in Khurasan and Jurjan habits. This may be the origin of his name, al-Gazâli. ${ }^{12}$ However, this story is still not clear yet. Khallikan, quoted from Ibn al-Sam'ānī, a historian from Persia who was close to al-Gazālī after 'Abd alGhafir al-Fārisī, stated that al-Gazāli name was derived from the name of his home town Gazālah. ${ }^{13}$ However Yaqut (d. 626/ 1228), the geographers who visited the Tus in the 13th century, did not mention the name of the village in Mu'jam al-Buldan. ${ }^{14}$

Al-Juwayn $\overline{1}^{-15}$ is probably the most influential teacher in shaping the theological and philosophical thought of al-Gazālí. As shown by Griffel, al-Juwayni was a reformer of Asy'ari

Șirayfīnī, al-Muntakhab min al-Siyāq li-Tärikeh Naysäbūr, ed. M.A.'Abdal- Azīz (Beirut: Dār al-Kutub al-`Ilmiyyah, 1989), 73-75.

IIbn al-Jawzī, Al-Muntaz̧am fi Tärikh al-Mulük wa al-Umam, ed. Muhammad and Muștafā 'Abd al-Qādir 'Ạtā (Beirut: Dār al-Kutub al'Ilmiyyah, 1992), 124.

${ }^{10}$ Abū Abbās Shams al-Dīn Ahmad ibn Muhammad ibn Abī Bakr ibn Khallikān, Wafayāt al-A'yān wa Anbä' Abnā' al-Zamān, ed. Iṇsān 'Abbās (Beirut: Dār Șādir, 1968-72), 218.

${ }^{11}$ Frank Griffel, al-Garälì's Philosophical Theology (Oxford: Oxford University Press, 2009), 25. Griffel explained his argument clearly in pages 23-25.

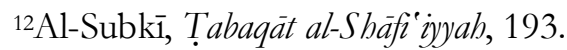

${ }^{13} \mathrm{Ibn}$ Khallikān, Wafayāt al-A'yān, 98. 49-50.

14Yāqūt al-Ḥamawī, Mưjam al-Buldān (vol. 5) (Beirut: Dār Ṣādir, 1977),

${ }^{15}$ About the life and works al-Juwaynī, see Paul L. Heck, "Jovayni, Emām al-Haramayn," in Encyclopedia Iranica (2009), ed. Ehsan Yarshater. Accessed on April 5, 2012 http://www.iranica.com/articles/jovayni-emamal-haramayn/. Look Ormsby, Ghazali, 27-29. 
theologian in the 11th century. He learned deeply the works of Ibn Sinā. Thereby, he realized that regardless of the fact that his thoughts become a serious challenge to the building thought of Ash'ariyyah. He also argued that the methodology of Ibn Sinna can also be used to update the Ash'ariy theology. ${ }^{16}$ His thought on the ontology and cosmology apparently began to abandon atomism and occasionalism taught by classical Asy'ari theologians. ${ }^{17}$ According to Robert Wisnovsky, al-Juwaynī together with contemporary Asy'ari theologians, pioneered the movement which he called "Avicennian tendency in Sunni theology."18

After the death of Al-Juwaynī, al-Gazālī decided to be the escort "wanderer palace" (Mu'askar) of Nizam al-Mulk. This Saljuk prime minister was attracted by the intelligence of alGazālī, raising a young intellectual as Nizamiyya professor in Baghdad in 1091. He held this position until 1094. This fouryear period was the period he wrote the books about theology and philosophy. In these years, he completed a trilogy of philosophy: Maqāsid al-Faläsifah, Tahäfut al-Faläsifah, and Mi'yār al-'Ilm. From those three books, the most chronicle writing is Tahäfut. Hourani notes that this book was completed on January 11 th 1095 or Muharram 488/21. ${ }^{19}$ Because Maqasid and Mi'yarr were written as a supplement of Tabäfut, they obviously served as further explanation of Tahäfut. ${ }^{20}$ Jules Janssens, who did the

${ }^{16}$ Griffel, al-Gazälì's Philosophical, 29-30.

${ }^{17}$ Ibid., 128-133.

18Robert Wisnovsky, "One Aspect of the Avicennian Turn in Sunnī Theology," Arabic Sciences and Philosophy 14, no. 1 (March 2004): 65-100.

${ }^{19}$ George F. Hourani, "A Revised Chronology of Gazālìs Writings," Journal of the American Oriental Society 104 (April-June 1984): 292-293.

${ }^{20}$ The researchers who wrote about the chronology of the al-Ghazali's works generally assumed, because of his eksposisional character, Maqāsid must have been written before Tahäfut, and Mïyär, because is an attachment of Tahäfut, written afterward. Look Maurice Bouyges, Essai de chronologie des curres de al-Ghazali (Algazel), ed. Michel Allard (Beirut: Imprimerie Catholique, 1959), 21-26; 'Abd al-Rạ̣mān Badawī, Mu'allafāt al-Gąălì (Beirut: Dār al-Qalam, 1977), 53-70; Hourani, "Revised Chronology," 292293. However, Frank Griffel argued that the chronology of these third works especially Maqāsid and Tabäfut are uncertain. There is a possibility that 
text analysis on Maqāsid and Míyār, argued that both of the texts were prepared under the shadow of al-Fārābī and Ibn Sinnā. Maqāsid seems to be al-Gazālī's translation of Ibn Sīnā's work in Persian, Dānish-Nämeh 'Alā'̀. Mi'yār contains summary of review of the logic in the works of al-Fārābī such as al-Qiyās alSaghir and al-Kitab al-Maqülät and the works of Ibn Sinnā like alNajät, al-Ishärät wa'l-Tanbihät, Dänish-Nämeh, and the book of alHudūd. ${ }^{21}$ Al-Gazāli also wrote the other exposition about the metaphysics called as $M i^{\prime}$ yar al-'Aql. Unfortunately, we have only its incomllete manuscript. ${ }^{22}$

In 1094, at the command of newly appointed caliph, AlMustazhir, al-Ghazali wrote Fadä'ih al-Bätiniyyah wa FaDäàil alMustaz̧biriyyah. It is a polemical treatise against the Shi'a Isma'ilis group. This sect becomes a serious threat to the Seljuq dynasty, both militarily and theologically. Two years earlier, precisely on the 10th of Ramadan 485/14 October 1092, Nizām al-Mulk was stabbed by a fidā'ì on his way between Isfahan and Baghdad. The fidā'i was directly killed without any interrogation. It caused many speculations about the mastermind behind this murder. ${ }^{23}$

Tahäfut was written earlier than Maqāsid; or that Maqāsid was not written as a prelude of Tahäfut. Look his argument in al-Gazälì's Philosophical, 35-36; also in Frank Griffel, "MS London, British Library Or. 3126: An Unknown Work by al-Gazālī on Metaphysics and Philosophical Theology," Journal of Islamic Studies 17, no. 1 (January 2006): 1-42. See also the analysis of the Gabriel Said Reynolds, "A Philosophical Odyssey: Gazālis Intentions of the Philosophers," in Medieval Philosophy and the Classical Tradition in Islam, Judaism and Christianity, ed. John Inglis (Richmond: Curzon Press, 2002), 30-41; and Ayman Shihadeh, "New Light on the Reception of al-Gazālie s Doctrines of the Philosophers (Maqàsid al-Faläsifa)," in In the Age of Averroes: Arabic Philosophy in the Sixth/Twelfth Century, ed. Peter Adamson, (London: The Warburg Institute, 2011), 77-92.

${ }^{21}$ See Jules Janssens, "Le Dānesh-Nämeh d'Ibn Sinnā: Un texte à revoir?” Bulletin de Philosophie Médiévale, no. 28 (1987): 163-177. together with "AlGazālīs Mieyār al- 'ilm fī fann al-mantiq sources avicenniennes et Fārābīennes," Archives d'bistoire doctrinale et littéraire du Moyen Age 69, no. 1 (2002): 39-66.

${ }^{22}$ About this book, look Griffel, "MS London," 1-42.

${ }^{23}$ See the different analysis expressed by the following writers: Omid Safi, Politics of Knowledge, 74-79; Griffel, al-Gazāil’’s Philosophical, 36-39. 
This tragedy marked political crisis of Saljūq Dynasty in subsequent years. A month later, Malik Shāh died because of a fever he suffered after hunting. Sudden death of Malik Shāh immediately stimulated political competition and rivalry amongst his children from three different mothers. At first, between Barkiyaruq and Mahmud supported his mother, Terken Khatun. Meanwhile, Taj al-Mulk, a rival who was subsequently appointed as a replacement of Niẓām al-Mulk, was killed by Niẓāmiyyah the supporters of Nizām al-Mulk. They accused Taj al-Mulk as the mastermind behind the murder of Nizām al-Mulk. This crisis ended with the death of Terken Khatun and her son, Mahmud, and the appointment of Berkiyaruq as sultan. ${ }^{24}$

As a leading Shāfi'ì cleric, al-Gazālī was active in defending the caliphate of 'Abbāsiyah on one side. He, on the other side, tried to delegitimize the claims of the groups who are often called the Bāṭiniyyah by his opponents. ${ }^{25}$ Al-Gazālì's moderate political position is driven by the desire to find a middle ground berween 'idealism' and 'real politics'. ${ }^{26} \mathrm{He}$ did not hesitate to criticize the political practice of the authorities that deviated from religious guidance. He also offered political advice to the sultan, and act as a mediator whenever there was disagreement between the caliph and sultan.

In the month of Dhü'l-Qa'dah 488/November 1095, alGazāī collapsed and suffered "spiritual crisis". ${ }^{27}$ According to 39.

${ }^{24}$ About This Political Events, look Griffel, al-Gazälit's Philosophical, 36-

${ }^{25}$ About Al-Gazāli's polemic against the Shi'a Isma'ilis, look Farouk Mitha, Al-Gazalĭ and the Ismailis: A Debate on Reason and Authority in Medieval Islam (London: I.B. Tauris cooperating with Institute of Ismaili Studies, 2001), 1-160.

${ }^{26}$ For the study of political thought of Al-Gazāili, look Henri Laoust, La politique de Gazàlì (Paris: Paul Geuthner, 1970), 45; also Carole Hillenbrand, "Islamic Orthodoxy or Realpolitike? Al-Gazälits Viens on Government," Iran 26 (1988): 81-94.

${ }^{27}$ This episode in the life of al-Gazâli has been studied and analyzed by researchers. See the diverse interpretations given by, among others, D.B. Macdonald, "The Life of al-Ghazzālī, with especial reference to his religious experiences and opinions," Journal of the American Oriental Society 20 January 1899): 71-132; Farid Jabre, "La biographie et l'œuvre de Ghazali reconsidérées à la lumière des TTabaqat de Sobki." Mélanges de l'Institut 
his own admission in his autobiography, al-Munqidh min al-Dalāl, the crisis was triggered by the inner consciousness that his motivation in the scientific and academic activity is just worldly interests. On the pretext of going to do the Hajj, he secretly traveled to Damascus, Jerusalem, Hebron, and Hijāz. In front of the tomb of Abraham in Hebron, he swore not to visit the ruler again, accept a position from the ruler, and engage in academic debates. ${ }^{28} \mathrm{He}$ lived in those cities for two years and after that decided to return to Baghdad because of his longing to his family. ${ }^{29}$ In these years, he completed his magnum opus about Sufism, Ibya a' 'Ulüm al-Din. When in Jerusalem, he wrote a small treatise on Asy'ari theology, which he slipped as a chapter three in second book of Ibyā' 'Ulüm al-Dìn, al-Risālah al-Qudsiyyah. ${ }^{30}$ According to his students who came from Maghreb, Abu Bakr Ibn al-'Arabi, al-Gazāī had arrived in Baghdad in 490/1097.31

In 1106, because of the insistence of Fakhr al-Mulk, alGazālī was willing to teach in Nizamiyya Nishapur, filling the position formerly held by his teacher, al-Juwayni. In this time, his thought appeared as the controversy. The conservative clerics, who read the works of "esoteric" al-Ghazali such as Ibyä, Mishkeàt al-Anwār and Kimiya'-yi Sa'ädat, argued that his thoughts in these books had deviated from tradition of Ash'ariyyah and mostly relied on the thinking of Muslim philosophers like Ibn Sinnā and Ikhwān al-Ṣafă', if it is not even the Zoroastrian

Dominicain d'Etudes Orientales 1 (1954):73; Kojiro Nakamura, "An Approach to Gazālîs Conversion," Orient 21 (February 1985): 46-59; Mustafa Abu-Sway, "Al-Gazālîs "Spiritual Crisise Reconsidered," AlShajarah 1, no. 1 \& 2 (1996): 77-94.

${ }^{28}$ The oath mentioned by al-Gazāīi in his letter to Diyā' al-Dîn Aḥmad ibn Nizām al-Mulk is that he wrote in 1110, a year before his death. See the translation of the letter in Jonathan A.C. Brown, "The Last Days of alGazâlī and the Tripartite Division of the Sufi World: Abū Hāmid al-Gazâlî̀s Letter to the Seljuq Vizier and Commentary," The Muslim World 96, no. 1 (January 2006): 89-113. The oath mentioned in pages 95.

${ }^{29} \mathrm{Al}-\mathrm{G} a z a \bar{l} \overline{1}$, al-Munqidh min al-Daläl, 38.

${ }^{30 H o u r a n i, ~ " R e v i s e d ~ C h r o n o l o g y, " ~ 295-297 . ~}$

${ }^{31} \mathrm{Abū} \mathrm{Bakr}$ Ibn al-'Arabī, al-'Awāsim min al-Qawāsinim, edited by 'Ammār Ṭâlibì (Kairo: Maktabah Dār al-Turāth, 1997), 24. Dānishmand, "a wise teacher," is a nickname in persian pinned by Ibn al- 'Arabī for al-Gazālí. 
teachings. A cleric from Maghrib was active in the campaign for opposing al-Gazālī. ${ }^{32}$

The opponents of al-Gazālī initially delivered a petition to Sanjar that al-Gazālī:

...don't have any conviction of Islam, otherwise, he embraced the belief of the philosophers and the heretics (falasifah wa mulbidan). He filled all his books with their words. He confounded the kufr (kufr) and the sleaze (abatiti) with the secrets of revelation. He called the true light of God and this is the belief of the Zoroastrians (madhhab-i majus), which teach the light and the darkness. 33

They seemed to have failed to oppose al-Gazālī. Thus, they took another path by scraping his past. Then they issued accusations that al-Gazālī had insulted Abu Hanifah in his work al-Mankbülmin Ta'liqa ' 'Ilm al-Usul. Sanjar was an adherent of the Hanafi. This accusation was really serious and expected to ignite the anger of the sultan. But, this attempt was unsuccessful as well. ${ }^{34}$

In this atmosphere, he wrote Faysal al-Tafriqah and his intellectual autobiography, al-Munqidh min al-Dalal. In the latter book, he offended the attack of the conservative clerics:

A group of people, who are not solid in the mastery of knowledge and have not yet reached the highest level in madhbab, count on our writings about the secrets of religious knowledge. They thought these phrases were collected from the ancient utterance [the Greek philosophers], although in part was the result of reflection [of our own] - a horse trail may be similar to the footprints of others and the other horses collected from the books about the Shari'ah, some others even contained in the books of the Sufis. Suppose those phrases were indeed only in their books, but if the expression can be accepted by logic,

${ }^{32} \mathrm{About}$ this figure, and the activities in the campaign against alGhazali, look Kenneth Garden, "Al-Māzarī al-Dhakī: Al-Gazālīs Maghribi Adversary in Nishapur," Journal of Islamic Studies 21, no. 1 (January 2010): 89107.

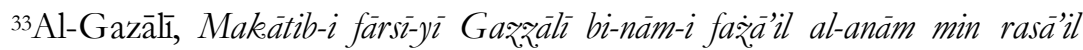
Hụjat al-Islām, ed. 'AbbāsIqbāl (Teheran: Kitābfurūshi-yi Ibn Sīnā, 1954), 3; quoted by Garden, "Al-Māzarī al-Dhakī," 93.

${ }^{34}$ Regarding these events, see Kenneth Garden, "Al-Gazālìs Contested Revival: Ihyā̄e Ulūm al-Dīnand Its Critics in Khorasan and the Maghrib" (Unpublished Ph.D dissertation. Department of Near Eastern Languages and Civilizations, University of Chicago, 2005), 76-143. 
supported by demonstration, and did not negate the Qur'an and Hadith, why should be discarded and abandoned? 35

Al-Gazālī spent the last years of his life in his native Tưus by practicing Sufism and teaching. However, the period of seclusion (uzla) is not without interruption. In 1110, Diyā' al-Dīn A ḥmad ibn Nizāām al-Mulk, Sanjar's brother, invited al-Gazālī to teach back in Nizamiyya Baghdad, replaced the Supreme Master who has just died, al-Kiyā' al-Harrāsī. He refused to say that he was no longer interested in "searching for pleasures" (talab biriyadati duny $\vec{a}$ ) and that his turn was over. ${ }^{36}$ And indeed shortly afterwards he followed the class comrades. He died in Tus on December 18, 1111.

Throughout his life, al-Gazālī has written no less than 400 books on various areas of Islamic studies especially law (fiqh), jurisprudence (usül figh), theology, philosophy, and mysticism. Because of al-Gazālī's breadth of encyclopedic knowledge, alGazālī's students often had difficulty in determining whether he was a foremost jurist, theologian, philosopher or sufi. However, despite of these difficulties, it is certain that al-Gazālī studied philosophy in depth and it affected the style and the character of his writings. His works are logical, systematic, and persuasive. In al-'Awāsim Miun al-Qawāsim, Abu Bakr Ibn al-'Arabi quoted the impression of a cleric namely Ahmad ibn Șālihal-jili who said that "[Al-Gazālī] steeped in encient studies (philosophy) in such a way to their concept (the philosophers) which dominant in his books." 37 Ibn al-'Arabi acknowledgment to his teacher's achievement is his efforts to adopt and assimilate the methodology of philosophy into the building of Islamic thought. When talking about his works in the field of logic for example, he argued that al-Gazāī has unleashed the syllogism from the elements of philosophy. ${ }^{38}$ These assessments and blasphemies which must be faced by Al-Gazāli in Nishapur, indicate that the

${ }^{35} \mathrm{Al}-\mathrm{Gazāli}$, al-Munqidh min al-Ḍaläl, 26.

36Brown, "Last Days," 94-95.

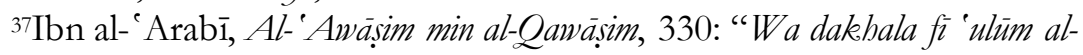
awàil ilà an qäla: wa galaba 'alayh isti' mälu 'ibärātibim fi kutubibi."

${ }^{38}$ Ibid., 78. 
philosophy has a significant influence on his thoughts even after he embraced the mysticism as the way of life.

\section{The Structure and the Content of Tahāfut al-Falāsifah}

In al-Munqidh min al-Daläl, al-Gazāli looked at the work of his Tahäfut as a "radd," rebuttal or response to the faläsifah. ${ }^{39}$ As explained by Gimaret, ${ }^{40}$ the book is titled as al-Radd 'Ala ... "response/answer to ..." has sprung up since the 2th H century/ 4th $\mathrm{M}$. The radd literature was intended as a rebuttal or response by a writer on the idea or thought of groups who disagree with the writer. In the field of theology or Kalam, relying heavily on dialectics or academic debate, ${ }^{41}$ this literature is abundant. The radd literature in theology (kalam) generally was arranged in the format of imaginary "discussion" with an opponent. In there, the opposing view is presented with details ("in qila ..."), followed by the writer's response ("fa-naquilu ...") such that at the end of the discussion of the establishment of the opponents appear to be inconsistent or contradictory. In short, the establishment was flawed. ${ }^{42}$ Tahäfut follow this strategy. From this perspective, Tahäfut actually is not a work that is unique in its genre.

Al-Gazālī arranged the Tahäfut in three core parts. The first part is introduction which consists of five sub-topics. The second part, which is the core of the book, is twenty chapters that contain the criticism of al-Gazālī on twenty philosophical problems that he saw were wrong. Sixteen problems come from the field of metaphysics; and the rest come from the natural

39Al-Gazālī, al-Munqidh min al-Dalāl, 18.

40Daniel Gimaret, "Radd," in Encyclopedia of Islam (Leiden: Brill, 1995), 8: 362b-363b.

"11 Josef van Ess, "The Beginnings of Islamic Theology," in The Cultural Context of Medieval Learning, ed. John E. Murdoch and Edith D. Sylla (Dordrecht: D. Reidel, 1975), 87-111. argued that Kalam came from and distinctively "dialogue" or "discussion"

${ }^{42}$ Frank Griffel, "Taqlìd of the Philosophers: Al-Gazàlīs Initial Accusation in his Tahafut," in Ideas, Images, and Methods of Portrayal: Insights into Classical Arabic Literature and Islam, ed. Sebastian Günther (Leiden: Brill, 2005), 276. 
sciences. The last part is conclusion or the cover which only consists of three short paragraphs.

In theintroduction, al-Gazâlī explained the background of Tabafut in the following paragraphs:

I saw a group of people who are surely different from their friends and colleagues through their unique intelligence and cleverness. They rejected the obligations in Islam related to worship, praying obligations, the prohibition from illicit goods and mocked the religious symbols. They also underestimate the worship and the provisions of Shari'ah. They did not want to hold back because of the provisions and the prohibition of Shari'ah. Otherwise, they completely broke away from the restraints of the religious teaching.

The base of their disbelief is just taqlid as it can be found among the Jews and the Christians ... and the speculative contemplation that arise since they stumbled on sophistic doubts that keep them away from the Truth ...

The source of their disbelief is that they heard the names of the great scholars [in the tradition of philosophy] such as Socrates, Hippocrates, Plato, Aristotle, and others. How ever, their followers' depiction of intelligence, an excess of their principles, and the details of their knowledge of geometry, logic, natural sciences, and metaphysics is excessively misleading. They explained that [the thought] they obtained merely with the ratio was able to find the conclusion. They also said that in addition to the highly intelligent and full of excess, the philosophers were also to deny the Shari'ah and religion. They rejected the details of the religious law because they are sure that the laws are only human creation and tricks.

When this information reached them, and the information about the teachings of [the philosopher] is accordance with their nature, they preened with kurf, in order to align with the sage, they said! They joined with the philosophers, exalteth himself above most people and the laity, and underestimated the complacency against the religious beliefs of their ancestors. They thought that exposing the intelligence by leaving to the right teaching of taqlid and then doing taqlid to the teachings that vanity is good. They did not realize that switching from a form of taqlid to the other taqlid is [a sign of] ignorance and confusion.43

Through the paragraphs above, al-Gazāli told us that Tahäfut was motivated by antagonism toward intellectuals' lifestyle that claims to be adherents of the teachings of philosophy. They are

${ }^{43} \mathrm{Al}-\mathrm{G} a z a \bar{l} \bar{i}$, Tahäfut al-Faläsifah, 1-2. 
reluctant to execute the commands of religion such as prayer or Shari'ah prohibitions such as drinking wine. This attitude, in his search, pushed by two things: First, the vanity and superior feelings over other thought and perspectives. Second, blind taqlid to the classical Greek philosophers. This taqlid departed from the assumption that all of the classical Greek philosophers' teachings, from mathematics till metaphysics, were derived from solid and demonstrative contemplation; it was impossible that they were wrong.

The accusation that the adherents of philosophy only made taqlid to "the great names" in their tradition is significant point to note. As the Asy'ari theologians used to be, Al-Gazālī created the opposition between 'ilm and taqlid or between 'ämma and khasșas. This is in contrast to the opposition of distinction status according to the level of the knowledges. 'Ammah group is mostly people who are not literate or do not have knowledge. They can only do follow others to gain knowledge or beliefs. Meanwhile, khässah is an educated class that is able to do his own reasoning without relying on others. In al-Iqtișād fi'l-I'tiqād, al-Gazālī explained that 'ilm al-kalàm is a fardhu kifaya science, the one whose obligation to pursue is communal and not personal, and that science is only mandatory for the educated who have the intelligence. ${ }^{44}$

Most people were enough to do taqlid to the clerics or the theologians. However, doing taqlid to others is a big mistake for intellectuals who are able to think by themselves. For this educated class, the only individual who deserves to be followed is the Prophet Muhammad. In Faysal al-Tafriqa, Al-Gazālī wrote:

If you ponder this problem honestly, you will realize that anyone who restricts the truth only on a thinker has approached to the disbelief and the hypocrisy. Firstly, he approached the kufr because he puts a thinker on par with the infallible Prophet... Secondly, he approached the hypocrisy because the job of a thinker to contemplation and taqlid is illegitimate for him. How could he talk [to the students], "You have to

${ }^{44} \mathrm{Abu}$ Hāmid Muhammad ibn Muhammad al-Gazālī, al-Iqtiṣād fìlI'tiqād, ed. Ibrāhīm A. Çubukçu and Huseyin Atay (Ankara: Nur Matbaasi, 1962), 11. 
think by yourself; but you also should not produce the distorted thought of my thoughts "... would not this be hypocritical?45

The Tahäfut was written to delegitimize the epistemological superiority claims which recognized by Falasifah. Al-Gazālī wanted to prove that not all of the teachings of the classical philosophers have reached the level of demonstrative as claimed by their followers. ${ }^{46}$ Thus, the purpose of The Tahäfut is fully destructive, not constructive. Through this work, he wanted to unload, did not build. BecauseTahäfut in terms of methodology is full of dialectical character. Al-Gazālī wrote:

Know that my goal [in this book] is to remind people who have a good prejudice to philosophers and believe that their method is free from contradiction with show [some] in terms of their confusion. For this reason, I would not argue with them except as a demanding and reneged, not one who claims [and] affirms. I will destroy their belief with [show] the consequences to the contrary. So, sometimes I would force them to follow the teachings of Mu'tazila, at other times Karrāmiya teachings, but at other times Wāqifiya teachings. However, I did not intend to defend one of these madhbabs. I just make the madhhabs as a weapon against them. ${ }^{47}$

Al-Gazālī reminded that we could not simply contrast philosophy with religion. According to him, there are three possible religious positions that opposed with the philosophy. The first is the difference which is just purely verbal problem, as is the habit of philosophers to refer to God as a "substance." According to him, the problem like this is not necessary disputed because in essence, both the philosophers and ordinary Muslims alike believe in the existence of God and argue that it will only end on the lexical dispute. ${ }^{48}$.

${ }^{45} \mathrm{Al}-\mathrm{Gazā} \overline{1}$, Faysal al-Tafriqah, 22-23. Bìjū text is using tanāqud words, "kontradiksi" for "hypocritical" my translation follows Griffel, "Taqlìd of the Philosophers," 281.

46Jules Janssens, "Al-Gazālìs Tahāfut: Is It Really a Rejection of Ibn Sīnā's Philosophy?” Journal of Islamic Studies 12, no. 1 (January 2001): 1-17, doing hujjah that the target of The Tahäfut attack "seems to be the philosophy of ancient [Greece], especially metaphysics, and acceptance of its teachings uncritically," is not Ibn Sinnā. This opinion seems rather hard to accept.

${ }^{47} \mathrm{Al}-\mathrm{Gazā} \overline{1}$, Tahāfut al-Faläsifah, 7-8.

48Ibid., 5 . 
The second aspect is the doctrine of the philosophers which did not contrary with the fundamentals of religion. Al-Gazāli divided the the field of philosophical studies into six fields: (a) the arithmetic, (b) logical, (c) the natural sciences, (d) metaphysics, (e) political and (f) ethics. ${ }^{49}$ Among the six fields of this study, Tahäfut poured out only to question a number of falasifah conclusions in the field of metaphysics and natural science. He did not refuse other fields such as politics, ethics, and even more arithmetic. He said "rejecting this issue is not a prerequisite of faith in the prophets and apostles." 50

The last aspect is the doctrine of the philosophers which obviously contrary to the fundamentals of religion as their teachings in the natural creation problem, the attributes of God, and the physical resurrection of the humand race on the Day of Judgment. ${ }^{51}$ According to him, Tahäfut was written to reject the doctrine of this last category. Twentieth chapters of Tabäfut are arranged in an imaginary dialogue format between al-Gazāī and Muslim philosophers. Every argument they advance is broken by al-Gazāli with the arguments which he had taken from the various sources.

Thereby, Al-Gazālī did not intend to delegitimize the logic of a methodology of thinking. He only intended to prove that a number of the falasifah theses in metaphysics and natural science did not reach a prerequisite demonstrative (burhan) as determined by their own. At the end of his Introduction of Tahäfut, al-Gazālī asserted:

We will show that in the field of metaphysics, they (the philosophers) are unable to fulfill the preconditions set out in the various parts of the logic and the introduction, as they described in the book Al-Burban about the terms of the truth of the syllogism, premise, and in the book of al-qiyas about the terms of the syllogism figure, and other things which they teach in Isagogedan Categoriae..$^{52}$

The twenty chapters of Tahäfut talk about the philosophical themes ranging from nature up to the physical resurrection of

\footnotetext{
${ }^{49} \mathrm{Al}-\mathrm{Gazā} \overline{1}$, al-Munqidh min al-Ḍaläl, 20-25.

${ }^{50} \mathrm{Al}-\mathrm{Gazāl} \overline{1}$, Tahāfut al-Falāsifah, 5-6.

51Ibid., 7.

52Ibid., 16. Compare with al-Gazātī, al-Munqidh min al-Ḍaläl, 22.
} 
on the Day of Resurrection. The problem is not whether these theses are right or wrong, but whether these theses can be proved demonstratively or not. Chapter 17 of Tabäfut, for example, explores the theory of causality, ${ }^{53}$ deployied to delegitimize the theory of causality of Ibn Sīnā. Here, al-Gazālì's goal is not to reject the theory of causality, but rather to destroy the thesis of Ibn Sinna that the causal relationship is necessary and essential; and that this thesis has achieved the demonstrative status. ${ }^{54}$ The strategy is currently suing demonstrability of Ibn Sinā's theory will probably remind us to the strategy of the empiricists such as David Hume. He wrote:

The relationship between something that is customarily believed as the cause and something that is believed as a result it is not necessarily in our opinion. Otherwise [if exist] two objects, where one is not the other, and the affirmation that the first object is not sure to affirm the existence of other objects as well as objects first negation is not necessarily negate the other objects, it is not necessarily the existence of the first objects that would require the presence of other objects and the absence of the first things that do not necessarily require the absence of other objects-for example, between satisfying the thirst and drinking, satiety and eating, burning and fire, light and the rising of the sun, death and beheadings, healing and taking medication, ... and the other examples that can be observed in the objects that are linked in medicine, astronomy, art, and skill. The interrelationship between the two is because of the ordinance of God who created it together, not because both are necessary and inseparable. On the contrary, [God] is able to create satiety without eating, death without beheading,

${ }^{53}$ This theme has been widely discussed and analyzed by the students of al-Gazālī. Among others are: Lenn E. Goodman, "Did al-Gazālī Deny Causality?" Studia Islamica, no. 47 (1978): 83-120; Ilai Alon, "Al-Gazāīi on Causality," Journal of the American Oriental Society 100, no. 4 (OctoberDecember 1980): 397-405; Michael E. Marmura, "Al-Gazālîs Second Causal Theory in the 17th Discussion of his Tabäfut," in Islamic Pbilosophy and Mysticism, ed. Parviz Morew edge (Delmar, N.Y.: Caravan Books, 1981), 85112; Stephen Riker, "Al-Ghazali on Necessary Causality in The Incoherence of the Philosophers," The Monist 79, no. 3 (1996): 315-324; George Giacaman and King Bahlul, "Gazālī on Miracles and Necessary Connection," Medieval Pbilosophy and Theology 9 (2000): 39-50; Leor Halevi, "The Theologian's Doubts: Natural Philosophy and the Skeptical Games of Gazāli," Journal of the History of Ideas 63, no. 1 (2002): 19-39.

"54Goodman, "Did al-Gazāili," 90; Griffel, al-Gazẩlì's Philosophical, 147. 
maintaining life after beheading, and so on. The philosophers rejected the the possibility of [this] and considered impossible. ${ }^{55}$

At a glance, a rebuttal of al-Gazālī above seems to defend the establishment of occasionalism about the nature. However, instead of defending Occasionalism, he emphasized the phenomenal characteristics of natural events such as the burning of fabrics after contacting with the fire and that the phenomenon can be explained by two theories, which are equally valid:

They did not have any evidence other than the observation that the combustion occurs after contacting with flame. Observation (mushähadah) only shown the events that took place after (al-busül 'indabu), not because (al-usüul bihi) [something else] and that there's no cause (illah) again in others. ${ }^{56}$

Then, Al-Gazâlī sequentially exposes both theories. The first is theory of occassionalism which argues that the only agent who creates the event scorching of the fabric is God, not the fire, whether directly or through an intermediary angel. ${ }^{57}$ The second theory explains that the object in the nature does have specific properties and causality, but in a secondary sense. The causal relationship arises because of the provision or the ordinance of God, not because its essence should be as such. ${ }^{58}$ Here, alGazālī did not explain which of two theories that he follows.

\section{Adaptation and Appropriation: Al-Gazālī’s Philosophy}

Al-Gazāli's rejection against a number of the philosophical theses in metaphysics and natural science implies that he did not object to their theses in other fields or even their approach and methodology in philosophy generally. He wanted to show the weakness of philosophical thoughts in these fields. Regarding the validity of the logic as a methodology of thinking, for example, he stressed that this science is the discipline of neutral knowledge. In his book in response to the Isma'ilis, al-Qistâs alMustaqim, al-Gazālī reads several verses which he patterns

\footnotetext{
${ }^{55} \mathrm{Al}-\mathrm{Gazāl} \overline{1}$, Tahāfut al-Falāsifah, 166.

56Ibid.,167.

57Ibid., 167.

58Ibid., 169-170.
} 
according to figures of categorical and disjunctive syllogism. ${ }^{59}$ Through this book, al-Gazâli certainly does not mean to say that the Aristotelian and Stoic syllogism are "supported" by the verses of the Qur'an, but that, in essence, the ratio and the revelation teach the same things and come to the equal conclusion. In Munqidz, al-Gazālī reminds every Muslim in order not to get stuck in one of two extreme attitudes in dealing with philosophy. The first is to blindly accept to anything that is taught by the philosophers without investigating the status and level of the truth. Many people seeing the ancient Greek philosophers as great experts who unrivaled in the field of the logic or mathematics conclude that their teachings on metaphysics must have the same degree of accuracy as mathematics. According to al-Gazālī, this is the error which arises because of blind taqlid. ${ }^{60}$

The second extreme attitude is that some believers who have strong religiosity but do not have enough base of knowledge (sadiq jähil) see philosophy in terms of its teachings. They perceive that all the ideas of the philosophers are wrong, even that has proved demonstratively by logic. They are in the sarcastic phrase of al-Gazāli. They thought that the religion of Islam is based on stupidity. They do not understand that such an attitude will endanger Islamic thought. It may incite a view that Islam is indeed a religion that against science or wisdom. ${ }^{61}$

For al-Gazālin, it seems that rejecting the demonstrability of philosophical theses is one thing; while accepting and utilizing these theses is something else. In Tahäfut, al-Gazālì emphasizes that philosophers are unable to prove "the existence of God," or that "God is one."62 But, of course it does not mean that alGazālī do not believe in the existence of God or monotheism.

${ }^{59} \mathrm{Al}-\mathrm{Gazā} \overline{1}$, al-Qistās al-Mustaqìm, ed. Victor Chelhot (Beirut: Dār alMashriq, 1983), 23-25. The best study about this book is Rosalind W. Gwynne, Logic, Rhetoric, and Legal Reasoning in the Qur'an: God's Arguments (London: Routledge Curzon, 2004); and Martin Whittingham, al-Gazāti and the Qur'an: One Book, Many Meanings (London: Routledge, 2007).

${ }^{60} \mathrm{Al}-\mathrm{Gazā} \overline{1}$, al-Munqidh min al-Ḍalàl, 21.

${ }^{61}$ Ibid., 21-22.

${ }^{62} \mathrm{Al}-\mathrm{Gazā} \overline{1}$, Tahäfut al-Faläsifah, vol.4 \& 5. 
Here, he just tries to show that the evidences advanced by Muslim philosophers do not reach demonstrative level. However, the thought that is not demonstrative is not necessarily wrong and can be utilized in other respects.

Al-Gazālî's attitude against the psychology of Ibn Sīnā is an interesting example. In Tahäfut, al-Gazālī provides a special chapter to criticize the psychology in chapters 18 and 19. However, it does not prevent him from utilizing the teachings of Ibn Sīnā to explain his own thoughts. This is what he did, for example, in Ibya' 'Ulum al-Din. This book is a manual on the practice of Sufism. In it, al-Gazālī invites Muslims to practice the teachings of the Shari'ah (mu'amalah) in the various fields. With this practice, it is expected they will get "enlightenment" or mukashafah, ${ }^{63}$ the highest knowledge in epistemological hierarcy of the sufis. However, when trying to explain the psychological foundation of this theory in Book XX of Ibya', he borrowed the theory of Ibn Sīnā about the psychology. ${ }^{64}$ In Mishkeàt al-Anwàr, he modifies the terminology preface when he wrote that human perception (rüh) is divided into five: (a) the spirit of sense (al-rüh al-ḥissì), (b) the spirit of imaginative (al-rūh al-khayāi ì), (c) intellectual spirit (al-rūh al-'aqli), (d) discursive spirit (al-rühalFikri), and the spirit of the holy Prophet (al-rühal-Qudsi alNabawr). ${ }^{65}$

Al-Gazâlî's rejection to the theory of of causality does not imply that he believes of extreme occasionalism or that he does not believe in the theory of causality. In Ibya, al-Gazāli warned Muslims:

${ }^{63}$ About both "key words" in tasaw uf of al-Gazāì, mu'ämalah and mukäshafah, see Avner Gil'adi, "On the Origin of Two Key-Terms in alĠazzālīs Ihyā̄' 'Ulūm al-Dīn,” Arabica 36, no. 1 (1989): 81-92.

${ }^{64} \mathrm{Al}-\mathrm{Gazā} \overline{1}$, Ibyà', 3: 5-7. See also Peter Heath, "Reading al-Gazālī: The Case of Psychology," in Reason and Inspiration in Islam: Theology, Philosophy and Mysticism in Muslim Thought, ed. Todd Lawson (London: I.B. Tauris in cooperation with Institute of Ismaili Studies, 2005), 185-199; Jamāl Rajab Sīdbī, Nazariyyat al-Nafs bayna Ibn Sinā wa al-Gazālì (Kairo: al Hay'ah alMiṣriyyah al- 'Āmmah li'l-Kitāb, 2000).

${ }^{65} \mathrm{Abu}$ Hāmid Muhammad ibn Muhammad al-Gazālī, The Niche of Lights (Mishkeat al-Anwār) English-Arabic edition, trans. David Buchman (Provo, Utah: Brigham Young University Press, 1998), 36-37. 
If you expected God to make you full without bread, or making bread moves to you, or order his angels to chew for you and watched it move to your stomach-it will only show the folly of his actions! ${ }^{66}$

He also utilizes the hierarchy of being introduced by Ibn Sinna to explain the meaning of a text of five levels of existence in Faysal al-Tafriqa. In this book, al-Ghazali explained that form which designated by a word in the text of Qur'ãn or Hadith has five possible existence: (a) The realization of essential (al-mujüd al-dhäti), (b) a form of sensory (al-wnjüd al-hissit), (c) the form of imaginative (al-wujūd al-khayäli), (d) intellectual form (al-wujūd alaqli), and (e) the metaphorical form (al-wujüd al-shibhi). ${ }^{67}$ This alGazālī's theory, as shown by Griffel, ${ }^{68}$ apparently levied from Ibn Sinā's theory about the inner senses (al-Hawass al-Batina). The conservative clerics attacked him in Nishapur when he was teaching at Nizamiyya. As a result, readers of al-Gazāī who switched from Tabäfut to his other works will get the impression that the book is called first; he was doing skeptical games against philosophy. ${ }^{69}$

Tahäfut is an influential book in the scientific tradition of Islam in subsequent periods. However, its impact should not be overstated. The book indeed refutes many aspects of philosophical view by Muslim philosophers and sparks other writings. ${ }^{70}$ Ironically, the main critics of Tahäfut are students or the heirs of al-Gazālī's own thoughts. The earliest was Fakhr alḌin al-Rāzì, eccentric Ash'ari theologian of the 12th century. In a series of public debate which he did in Iran, openly he discredited of Tahäfut and considered methodologically weak. ${ }^{71}$

${ }^{66} \mathrm{Al}-\mathrm{Gazā} \overline{1}$, Ibyà̄' 4: 249; quoted by Ormsby, Ghazali, 80.

${ }^{67} \mathrm{Al}-\mathrm{Gazāa}$, Faysalal-Tafriqah, 33-39.

${ }^{68} \mathrm{Griffel}, " \mathrm{Al}-\mathrm{G}$ azālî̀s Concept of Prophecy: The Introduction of Avicennan Psychology into Aše arite Theology," Arabic Sciences and Philosophy 14 (2004): 101-144.

${ }^{69 H a l e v i, ~ " T h e o l o g i a n ' s ~ D o u b t s ", ~} 25$.

${ }^{70}$ Regarding the earliest followers of al-Gazālī, especially in Iran, see Griffel, al-Gazälì's Philosophical, 61-95.

${ }^{71}$ Fakhr al-Dīn al-Rāzī, Munāzarāt Fakhr al-Dìn al-Rāzì fi Bilād Mā Warāal-Nahr, ed. Fathallah Kholeif (Bayrūt: Dār al-Mashriq, 1987), 60-61. See also Griffel, al-Gazāil’’s Philosophical, 116-120. 
In the West, a major critic of al-Gazāli is Ibn Rushd. ${ }^{72}$ He wrote Tahäfut al-Tahäfut to prove that the works of al-Gazàli was "largely has not reached yet the level of demonstrative [as he claims]." ${ }^{73}$ Finally, in the 15th century, Khojazādeh peeled the weaknesses of al-Gazālì's approach in responding to the teachings of the philosophy. ${ }^{74}$

The Recent studies about the development of the philosophy study and logic in the Islamic world after the 5th century/11th show that the assumptions and the generalizations (that Tahafut destroys philosophy in Islam) is exaggeration. ${ }^{75}$ According to Ansary, Tahäfut should be regarded as a representation of the emergence of Nominalist criticismagainst Aristotelian philosophy. ${ }^{76}$ Nominalism is usually understood as a school of thought which rejects the existence of abstract

${ }^{72}$ Here may be so important to emphasize that the terms of the genealogy of thought, Ibn Rushd was a disciple or the followers of al-Gazāit. He was a disciple of Abū Ja far al-Turjāī and Abū Bakr Ibn al- 'Arabī. The last, we know, direct disciple of Dānishmand. Debt of gratitude Ibn Rushd to al-Gazāli is bigger than which we assume. He among other things wrote an overview of the major works of al-Gazāin about the origin of figh, alMustasfa $\bar{a}$. His theory about the text interpretation method is also levied from the view of al-Ghazali. See Frank Griffel, "The Relationship between Averroes and al-Gazālī as it presents itself in Averroes "e Early Writings, especially in his Commentary on al-Gazālīe s al-Mustașfā," in Medieval Philosophy and the Classical Tradition in Islam, Judaism and Christianity, ed. John Inglis (Richmond: Curzon Press, 2002), 51-63.

${ }^{73} \mathrm{Ibn}$ Rushd, Tahäfut al-Tahāfut, ed. Muhammad 'Ābid al-Jābirī (Beirut: Markaz Dirāsāt al-Waḥdah al- 'Arabiyyah, 1998), 105.

${ }^{74}$ See Ayman Shihadeh, "Khojazāda on al-Gazālìs Criticism of the Philosophers: Proof of the Existence of God," in Proceedings of International Symposium on Khojazada, ed. Tevfik Yücedoğru, OrhanKoloğlu, MuratKılavuz, and Kadir Gömbeyaz (Bursa: Bursa Büyükşehir Belediyesi, 2011), 141-161.

${ }^{75}$ See other, A.I. Sabra, "The Appropriation and Subsequent Naturalization of Greek Science in Medieval Islam: A Preliminary Statement," History of Science 25 (September 1987): 223-243.

76 About this school, see Gonzalo Rodriguez-Pereyra, "Nominalism in Metaphysics," in The Stanford Encyclopedia of Philosophy, ed. Edward N. Zalta (Fall 2011 Edition). Accessed on April 5, 2012 http:/ / plato.stanford.edu/archives/fall2011/entries/ nominalismmetaphysics/ 
objects or the universal in metaphysics. Through Tahäfut, alGazāī challenges the Peripatetic philosopher to prove their theses elegantly. He challengs them not to be dogmatic in scientific discourse because science is always open to critics.

\section{Conclusion}

This article has provided some critical analyses about alGazālī's views on philosophy and the role of Tahäfut al-Falasifa in it. Al-Gazālī wrote Tahāfut for contestation against the superiority claims of philosophy epistemological superiority claims. In the 20 chapters of this book, he rejected the claim that the conclusions of the classical philosophers (in particular themes in the field of metaphysics and natural science) had achieved the status of a demonstrative argument. Thereby, al-Gazālī's criticism against philosophers is simply directed at their conclusions. He was not questioning the validity of the logic of the methodology of philosophical reasoning. In contrast, al-Gazālī accepts the logic of methodology and demonstrative criteria (burban/apodeixis) as a tool to measure the scientific truth and takes advantage of this methodology to sue the philosophical conclusions. Thus, alGazāli is fully rationalist in his thought.

The role of al-Gazâlī in the development of philosophy in Islam should not be seen as a destructive. The criticism of alGazālī in Tahäfut can not be seen as a reaction to the philosophical dogma or orthodoxy. He should be seen as a Muslim cleric who holds an important role in naturalization and adaptation of the Greek philosophical tradition into the building of Islamic thought. Al-Gazālī is an eclectic thinker and tends to be synthesis. He rejectes parts of Muslim philosopher's views that he thinks are contrary to fundamental Islamic principles while adopting and modifying other parts which are free from contorversies. For example, he advocated using Aristotelian logic in jurisprudence (usul fiqh) and theology (kalam), neoPlatonic cosmology and Avicennian psychology in theology and mystical teachings. After the death of al-Gazālī, the philosophy has ceased to be a school of thought that stands alone. However, the particular aspects of his thought system are 
absorbed and integrated into the system of theology or mysticism.

\section{References}

Abu-Sway, Mustafa. "Al-Gazālīs 'Spiritual Crisis' Reconsidered." Al-Shajara 1, no. 1 \& 2 (1996): 77-94.

Alon, Ilai. "Al-Gazālī on Causality." Journal of the American Oriental Society 100, no. 4 (October-December 1980): 397-405.

Ansary, Tamim. Destiny Disrupted: A History of the World through Islamic Eyes. New York: PublicAffairs, 2009.

Badawī, 'Abd al-Raḥmān. Mu'allafāt al-Gazāì̄. Beirut: Dār alQalam, 1977.

Bosworth, C.E. "The Political and Dynastic History of the Iranian World (A.D. 1000-1217)." In The Cambridge History of Iran, Vol. 5: The Saljuq and Mongol Periods edited by J.A. Boyle. Cambridge: Cambridge University Press, 1968.

Bouyges, Maurice. Essai de chronologie des cuvres de al-Ghazali (Algazel). Edited by Michel Allard. Beirut: Imprimerie Catholique, 1959.

Böwering, Gerhard. "Ğazālī, i. Biography." In Encyclopedia Iranica edited by Ehsan Yarshater. New York: Bibliotheca Persica Press, 2001.

Brown, Jonathan A.C. "The Last Days of al-Gazālī and the Tripartite Division of the Sufi World: Abū Hāmid alGazālī's Letter to the Seljuq Vizier and Commentary." The Muslim World 96, no. 1 (January 2006): 89-113.

Fakhry, Majid. A History of Islamic Philosophy (3rd edition). New York: Columbia University Press, 2004.

Garden, Kenneth. "Al-Gazālī’s Contested Revival: Ibyà' 'Ulūm al-Din and Its Critics in Khorasan and the Maghrib." Unpublished Doctoral Thesis., Department of Near Eastern Languages and Civilizations, University of Chicago, 2005.

. "Al-Māzarī al-Dhakī: Al-Gazālī’s Maghribi Adversary in Nishapur," Journal of Islamic Studies 21, no. 1 January 2010): 89-107. 
Al-Gazālē, Abū Hẹāmid Muḥammad ibn Muḥammad. Ibyà' 'Ulūm al-Dìn. Beirut: Dār al-Ma rifah, 1982.

. The Incoherence of the Pbilosophers (Tahäfut al-Faläsifab):

English-Arabic Edition, edited and translated by Michael E.

Marmura. Provo, Utah: Brigham Young University Press, 2000.

- Al-Iqtiṣād fíl-I'tiqād, edited by Ibrāhīm A. Çubukçu and Huseyin Atay. Ankara: Nur Matbaasi, 1962.

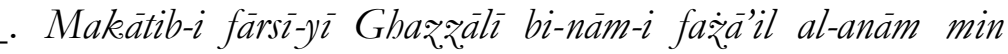
rasā'il Hụjat al-Islām, edited by 'Abbās Iqbāl. Teheran: Kitābfurūshi-yi Ibn Sīnā, 1333/1954.

- Al-Munqidh min al-Dalāl (Erreur et délivrance): ArabicFrench Edition, edited and translated by Farid Jabre. Beirut: Commission Libanaise pour la Traduction des Chefs-d'Oeuvre, 1969.

- Al-Mustasfā min 'Ilm al-Ușül, edited by Hamzah ibn Zuhayr Hāāiz. Madinah: al-Jāmie ah al-Islāmiyyah, Kulliyyat al-Sharī ah, 1413 H/1992-3 M.

. The Niche of Lights (Mishkāt al-Anwār): English-Arabic Edition, edited and translated by David Buchman. Provo, Utah: Brigham Young University Press, 1998.

- Al-Qistās al-Mustaqim, edited by Victor Chelhot. Beirut: Dār al-Mashriq, 1983.

Giacaman, George, and Raja Bahlul, "Ghazali on Miracles and

Necessary Connection." Medieval Philosophy and Theology, 9 (2000): 39-50.

Gil'adi, Avner. "On the Origin of Two Key-Terms in alGazzālì’s Ihyyā' 'Ulūm al-Dīn.” Arabica 36, no. 1 (1989): 81-92.

Gimaret, Daniel. "Radd." In Encyclopaedia of Islam, 2nd edition. Edited by C.E. Bosworth, E. van Donzel, et al., 362b363b. Leiden: Brill, 1995.

Goodman, Lenn E. "Did al-Gazālī Deny Causality?” Studia Islamica, no. 47 (1978): 83-120.

Griffel, Frank. "Al-Ġazālì's Concept of Prophecy: The Introduction of Avicennan Psychology into Aš arite 
Theology." Arabic Sciences and Philosopby 14 (2004): $101-$ 144.

- Al-Gazālì's Philosophical Theology. Oxford: Oxford University Press, 2009.

- "MS London, British Library Or. 3126: An Unknown Work by al-Gazālī on Metaphysics and Philosophical Theology." Journal of Islamic Studies 17, no. 1 (January 2006): 1-42.

. "The Relationship between Averroes and al-Gazālī as it presents itself in Averroes' Early Writings, especially in his Commentary on al-Gazālī's al-Mustasfä." In Medieval Philosophy and the Classical Tradition in Islam, Judaism and Christianity. Edited by John Inglis, 51-63. Richmond: Curzon Press, 2002.

"Taqlìd of the Philosophers: Al-Gazālī's Initial Accusation in his Tahäfut." In Ideas, Images, and Methods of Portrayal: Insights into Classical Arabic Literature and Islam. Edited by Sebastian Günther, 276. Leiden: Brill, 2005.

Gwynne, Rosalind W. Logic, Rhetoric, and Legal Reasoning in the Qur'àn: God's Arguments. London: RoutledgeCurzon, 2004.

Halevi, Leor. “The Theologian's Doubts: Natural Philosophy and the Skeptical Games of Gazâlī." Journal of the History of Ideas 63, no. 1 (2002): 19-39.

Heath, Peter. "Reading al-Gazālì: The Case of Psychology." In Reason and Inspiration in Islam: Theology, Philosophy and Mysticism in Muslim Thought. Edited by Todd Lawson, 185199. London: I.B. Tauris \& Institute of Ismaili Studies, 2005.

Heck, Paul L. "Jovayni, Emām al-Haramayn." In Encyclopaedia Iranica. Edited by Ehsan Yarshater, 2009. Accessed on April 5, 2012 http://www.iranica.com/articles/jovayniemam-al-haramayn/

Hillenbrand, Carole. "Islamic Orthodoxy or Realpolitik? AlGazālì’s Views on Government.” Iran 26 (1988): 81-94.

Hourani, George F. "A Revised Chronology of Gazâlī’s Writings." Journal of the American Oriental Society 104 (AprilJune 1984): 289-302. 
Ibn al- Arabī, Abū Bakr. Al-'Awāṣim min al-Qawāṣim, edited by 'Ammār Tālibī. Kairo: Maktabah Dār al-Turāth, 1997.

Ibn 'Asākir. Tabyīn Kadhib al-Muftarì fìmā Nusiba ilā al-Imām AbìlHasan al-Ash arì. Damaskus: Maṭa at al-Tawfiq, $1347 \mathrm{H}$. Ibn al-Jawzī. Al-Muntazam fì Tärīkh al-Mulūk wa'l-Umam, edited by Muḥammad and Muștafā 'Abd al-Qādir 'Ațā. Beirut: Dār al-Kutub al- ${ }^{\circ} I l m i y y a h, 1992$.

Ibn Khallikān, Abū Abbās Shams al-Dīn Aḥmad ibn Muhammad ibn Abī Bakr. Wafayāt al-A'yān wa Anbä' Abnā' al-Zamān, edited by Iḥsān 'Abbās. Beirut: Dār Ṣādir, 1968-1972.

Ibn Rushd, Abū al-Walīd. Tahāfut al-Tahāfut, edited by Muḥammad 'Ābid al-Jābirī. Beirut: Markaz Dirāsāt alWahdah al- Arabiyyah, 1998.

Ibn Tufayl. Hayy ibn Yaqzān: A Philosophical Tale, translated by Lenn E. Goodman. New York: Twayne Publishers, 1972. Jabre, Farid. "La biographie et l'œuvre de Ghazali reconsidérées à la lumière des Tabaqat de Sobki." Mélanges de l'Institut Dominicain d'Etudes Orientales 1 (1954): 73-102.

Janssens, Jules. "Le Dānesh-Nāmeh d'Ibn Sīnā: Un texte à revoir?" Bulletin de Philosophie Médiévale 28 (1987): 163-177.

- "Al-Ghazzālī’s Mi'yār al-'ilm fí fann al-mantiq: sources avicenniennes et Fārābīennes." Archives d'bistoire doctrinale et littéraire du Moyen Age 69, no. 1 (2002) : 39-66.

. "Al-Ghazzālī's Tahäfut. Is It Really a Rejection of Ibn Sīnā's Philosophy?.” Journal of Islamic Studies 12, no. 1 (2001): 1-17.

Laoust, Henri. La politique de Gazāilì. Paris: Paul Geuthner, 1970.

Mitha, Farouk. Al-Garāil and the Ismailis: A Debate on Reason and Authority in Medieval Islam. London: I. B. Tauris \& Institute of Ismaili Studies, 2001.

Ormsby, Eric L. Ghazali. Oxford: Oneworld, 2007.

Macdonald, D.B. "The Life of al-Ghazzālī, with especial reference to his religious experiences and opinions." Journal of the American Oriental Society 20 (1899): 71-132. 
Malamud, Margaret. "Sufi Organizations and Structures of Authority in Medieval Nishapur." International Journal of Middle East Studies 26 (1994): 427-442.

Marmura, Michael E. "Al-Gazālī's Second Causal Theory in the 17th Discussion of his Tahäfut." In Islamic Philosophy and Mysticism. Edited by Parviz Morewedg, 58-112. Delmar, N.Y.: Caravan Books, 1981.

Melchert, Christopher. "Sufis and Competing Movements in Nishapur." Iran 39 (2001): 237-247.

Nakamura, Kojiro. "An Approach to Gazālī's Conversion." Orient 21 (1985): 46-59.

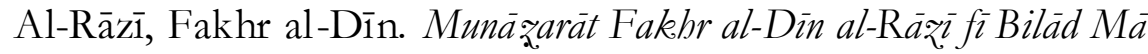
Warä' al-Nahr, edited by Fathallah Kholeif. Beirut: Dār alMashriq, 1987.

Reynolds, Gabriel Said. "A Philosophical Odyssey: Ghazzālī’s Intentions of the Philosophers." In Medieval Philosophy and the Classical Tradition in Islam, Judaism and Christianity. Edited by John Inglis, 30-41. Richmond: Curzon Press, 2002.

Riker, Stephen. "Al-Ghazali on Necessary Causality in The Incoherence of the Philosophers." The Monist 79, no. 3 (1996): 315-324.

Rodriguez-Pereyra, Gonzalo, "Nominalism in Metaphysics." In The Stanford Encyclopedia of Philosophy (Fall 2011 Edition). Edited by Edward N. Zalta. Accessed on April 5, 2012 http:/ / plato.stanford.edu/archives/fall2011/entries/no minalism-metaphysics/

Safi, Omid. The Politics of Knowledge in Premodern Islam: Negotiating Ideology and Religious Inquiry. Chapel Hill: The University of North Carolina Press, 2006.

Shihadeh, Ayman. "Khojazāda on al-Gazālī's Criticism of the Philosophers' Proof of the Existence of God." In Proceedings of International Symposium on Khojazada (22-24 October 2010 Bursa). Edited by Tevfik Yücedoğru, Orhan Koloğlu, Murat Kılavuz, and Kadir Gömbeyaz, 141-161. Bursa: Bursa Büyükşehir Belediyesi, 2011.

. "New Light on the Reception of al-Gazālī's Doctrines of the Pbilosophers (Maqāsid al-Faläsifa)." In In the Age of Averroes: Arabic Philosophy in the Sixth/Twelfth Century. 
Edited by Peter Adamson, 77-92. London: The Warburg Institute, 2011.

Sīdbī, Jamāl Rajab. Nazariyyat al-Nafs bayna Ibn Sinà wa al-Gazălì. Kairo: al-Hay'ah al-Mișriyyah al- ${ }^{-} \bar{A}$ mmah li'l-Kitāb, 2000. Al-Ṣirayfin̄ī, Ibrāhīm ibn Muḥammad. al-Muntakhab min al-Siyāq li-Tārikeh Naysābūr, edited by M.A. 'Abd al-'Azīz. Beirut: Dār al-Kutub al- ${ }^{-}$Ilmiyyah, 1989.

Al-Subkī, Tāij al-Dīn. Tabaqāt al-Shäfi ìyyah al-Kubra, edited by 'Abd al-Fattāḥ M. al-Ḥilw \& Mạ̣mūd M. al-Tanāḥī, 10 jilid. Kairo: Maṭba ah 'Īsā al-Bābī al-Halabīi, 1968.

Trimingham, J. Spencer. The Sufi Orders in Islam. Oxford: Oxford University Press, 1971.

Van Ess, Josef. "The Beginnings of Islamic Theology." In The Cultural Context of Medieval Learning. Edited by John E. Murdoch and Edith D. Sylla, 87-111. Dordrecht: D. Reidel, 1975.

Whittingham, Martin. Al-Gazāì and the Qur'ān: One Book, Many Meanings. London: Routledge, 2007.

Wisnovsky, Robert. "One Aspect of the Avicennian Turn in Sunnī Theology." Arabic Sciences and Philosophy 12 (2002): 65-100. 